\title{
Angiotensin Il: a key mediator in the development of liver fibrosis and cancer
}

\author{
Sameh Saber
}

\begin{abstract}
Background: Liver fibrosis and its outcomes of cirrhosis and hepatocellular carcinoma are major worldwide health problems and due to the complicated molecular pathogenesis, the options for effective systemic cure are relatively restricted. Angiotensin-converting enzyme inhibitors and angiotensin II receptor blockers, having well established safety profiles and low economic costs, may provide synergistic effects to existing chemotherapies by reducing angiotensin II-mediated angiogenesis, fibrogenesis, mitogenesis, metastasis, and oxidative stress.

Conclusion: These effects suggest angiotensin II inhibitors as promising agents for further clinical trials in the management of patients with fibrotic diseases.
\end{abstract}

Keywords: Fibrosis, Hepatocellular carcinoma, Renin-angiotensin system, Angiotensin ॥

\section{Introduction and aim}

Owing to the complex molecular pathogenesis of fibrosis and its outcomes of cirrhosis and hepatocellular carcinoma, the possibility for effective systemic treatment is relatively limited. Angiotensin-converting enzyme inhibitors and angiotensin II receptor blockers may provide synergistic effects to existing chemotherapies by reducing angiotensin II-mediated angiogenesis, fibrogenesis, mitogenesis, metastasis, and oxidative stress along with dilation of the tumor vessels, leading to improved overall drug delivery.

\section{Hepatic fibrosis}

Long-lasting liver damage due to various etiologies is the leading cause of liver fibrosis. It is primarily characterized by increased accumulation and unbalanced degradation of extracellular matrix (ECM) (Beljaars et al. 2002; Baiocchini et al. 2016). Around six times more ECM than normal is found in the liver at progressive stages, including collagens I, III, and IV. Reduced activity of metalloproteinases (MMPs), the main ECM-removing mediators, is predominantly due to an overproduction of tissue inhibitors of metalloproteinases (TIMPs), which are the

\section{Correspondence: sampharm81@gmail.com}

Department of Pharmacology, Faculty of Pharmacy, Delta University for Science and Technology, International Coastal Road, +11152, Gamasa, Mansoura, Dakahlia, Egypt specific inhibitors (Arthur 2000; Arpino et al. 2015). ECM proteins interfere with the hepatic architecture when they are developed by building up fibrous scars (Parsons et al. 2007); ultimately, the development of nodules of regenerating hepatocytes characterizes the framework of cirrhosis (Schuppan and Afdhal 2008). Owing to the high prevalence of fibrosis and cirrhosis in the general population (Poynard et al. 2010), molecular abnormalities of the liver and their relation to fibrosis have been of particular interest (Karsan et al. 2004).

Liver fibrosis is a result of the wound-healing response to repetitive cycles of damage and repair in the liver in which parenchymal cells regenerate and substitute the necrotic tissue (Hayes and Chayama 2016). Concomitant with these processes, an inflammatory response and a regulated deposition of ECM are established. If the damage persists, then eventually liver regeneration is failed, with the replacement of parenchymal cells with excessive ECM. As these fibrotic changes continue, a transition from collagen bands to bridging fibrosis to frank cirrhosis happens (Bataller and Brenner 2005; Sayyed et al. 2016).

Hepatic stellate cells (HSCs) are the principal ECM-producing cells of the damaged liver (Gabele et al. 2003; Hyun et al. 2016). Normally, HSCs exist in the space of Disse. Following persistent hepatic injury, they differentiate into myofibroblast-like cells of 
pro-inflammatory and fibrogenic activities (Milani et al. 1990; Marra 1999; Schon et al. 2016). Upon activation, HSCs travel to the sites of damage and repair and starts to produce and secrete large amounts of ECM (Lindquist et al. 2000; Wang et al. 2016).

Injured liver produces reactive oxygen species (ROS) and fibrogenic mediators and provokes the recruitment of white blood cells by inflammatory cells (Lan et al. 2015). Apoptosis of parenchymal cells stimulates the fibrogenic activities of myofibroblasts. Polymorphnuclear leukocytes and lymphocytes induce HSCs to produce and secrete collagen. HSC transactivation is also influenced by paracrine cytokines, platelet-derived growth factor (PDGF), tumor necrosis factor-alpha (TNF- $\alpha)$, transforming growth factor-beta (TGF- $\beta$ ), etc. that are synthesized by kupffer cells (KCs). Further, chemokines and cell adhesion molecules and their receptors are expressed by activated HSCs (Vinas et al. 2003; Riether et al. 2015). Therefore, inflammatory and fibrogenic cells stimulate each other and a complex interaction occurs in the course of liver fibrogenesis between different hepatic cell types (Maher 2001).

Cytokines have a major pro-fibrotic role in regulating liver fibrogenesis in response to injury in vivo and in vitro (Marra 2002). Amongst them, TGF- $\beta 1$ appears to be a central mediator in hepatic fibrogenesis (Gressner et al. 2002). TGF- $\beta$ favors the transactivation of HSCs into myofibroblasts and prevents ECM degradation. Strategies aimed at inhibition of TGF- $\beta 1$ synthesis and/or signaling markedly ameliorated liver fibrosis in experimental models (Shek and Benyon 2004; Xu et al. 2016).

In addition, PDGF, TNF- $\alpha$, interleukin (IL)-6, IL-1 $\beta$, and IL-13 are also key pro-fibrotic mediators, pharmacological inhibition, and/or gene deletion of these cytokines prevented the progression of hepatic fibrosis (Schwabe et al. 2003; Kaviratne et al. 2004; Sudo et al. 2005). Furthermore, vasoconstrictors (e.g., norepinephrine, angiotensin II (Ang-II)) (Oben and Diehl 2004; Han et al. 2017), and endothelin (ET)-1 (Cho et al. 2000; Correia-Costa et al. 2016) exert potent fibrogenic activities, while vasodilators (e.g., nitric oxide (NO), relaxin) have opposite actions (Iwakiri 2015).

Ang-II is a vasoactive component of the renin-angiotensin system (RAS) that seems to play a principal role in hepatic fibrosis (Iwakiri 2015); it induces production of inflammatory cytokines, mitogenesis, proliferation, and collagen synthesis in activated HSCs (Bataller et al. 2003a). Inhibition and/or gene knockout of Ang-II significantly attenuated experimental liver fibrosis (Yao et al. 2004a). Notably, the main components of RAS are expressed in injured liver tissues locally (Ahmadian et al. 2016), and activated HSCs can synthesize Ang-II (Yoshiji et al. 2002a).

\section{RAS contribution to fibrosis development}

Angiotensin-converting enzyme (ACE) catalyzes the conversion of the Ang-I into Ang-II; several reports proposed that Ang-II plays a crucial role in hepatic fibrogenesis (Saber et al. 2018a), and an Ang-II inhibitor or receptor blocker significantly attenuated hepatic fibrosis development and progression (Rippe and Brenner 2004; Yao et al. 2004b; Saber et al. 2017; Saber et al. 2018b). ACE is synthesized by hepatic KCs and is detected at the gene level in trans-activated HSCs (Bataller et al. 2003b; Huang et al. 2015). Proliferating bile duct epithelial cells, hepatic inflammatory cells, and activated HSCs are potential sources of $\mathrm{ACE}$ in the bile duct ligation liver model of fibrosis (Paizis et al. 2002). The normal level of ACE expression and activity in normal liver tissue is considerably upregulated in the bile duct ligation model of rat liver (Paizis et al. 2002). The distribution of liver ACE is generally found increased in areas of active fibrogenesis following bile duct ligation. In addition, the increased serum activity of ACE in cirrhotic patients suggests also that ACE has a critical role in hepatic fibrosis (Huskic et al. 1999; Noguchi et al. 2017).

Blockade of Ang-II can inhibit the progression of hepatic fibrosis in animal models (Yoshiji et al. 2005). Perindopril and candesartan were found to attenuate hepatic fibrosis and reduce the expression of alpha smooth muscle actin ( $\alpha$-SMA) (Yoshiji et al. 2001a) and TGF- $\beta 1$ (de Oliveira da Silva et al. 2017). Captopril delayed the progression of hepatic fibrosis in a model of rat bile duct ligation and was strongly associated with a decrease of collagen gene expression and TGF- $\beta 1$ (Jonsson et al. 2001). TGF- $\beta 1$ expression upregulated by Ang-II parallels overproduction of ECM proteins (Yoshiji et al. 2001a; Sui et al. 2015). Ang-II also upregulates $\alpha$-SMA (Meng et al. 2015) and downregulates E-cadherin (Nguyen et al. 2016), both of which control epithelial mesenchymal transition (EMT) (Liu et al. 2007).

Tissue inhibitors of metalloproteinases, particularly the TIMP-1, are markedly increased both in humans and murine liver fibrosis (Arpino et al. 2015; Iredale 1997). TIMP-1 was found to boost the development of hepatic fibrosis in a transgenic mouse model (Yoshiji et al. 2000). A marked reduction in the TIMP-1 expression level was linked to resolution of fibrosis following matrix remodeling in a rat model of hepatic fibrosis (Iredale et al. 1998). In addition, the TIMP-1 expression level was significantly upregulated by Ang-II in hepatic myofibroblasts in a time- and dose-dependent manner (Caley et al. 2015). Parallel to TIMP-1 inhibition perindopril significantly attenuated hepatic fibrosis development. Moreover, Candesartan and LY333531 (a protein kinase C (PKC) inhibitor) abolished TIMP-1 mRNA increase by Ang-II in a dose-dependent manner suggesting PKC signaling 
pathway in the fibrogenic effect of Ang-II (Yoshiji et al. 2003).

It was found that Ang-II increased TGF- $\beta$ and fibronectin mRNA expression in KCs that found to express the angiotensin II type 1 (AT1) receptor (Leung et al. 2003). One report stated that KCs induced with Ang-II demonstrated marked increase in the mRNA expression levels of TGF- $\beta 1$, TNF- $\alpha$, and fibronectin, and these levels were effectively decreased by saralasin and losar$\tan$ (Leung et al. 2003). Therefore, Ang-II has a critical role in the fibrotic process and the interaction of Ang-II and AT1 receptor is one of the foremost regulatory pathways in the development of liver fibrosis.

Mast cells are capable of producing TGF- $\beta 1$ and ECM components. AT1 receptor was found expressed in liver mast cells in the murine bile duct ligation (BDL) model of liver fibrosis (Paizis et al. 2002).

Angiogenesis is a vital process in both hepatic fibrogenesis (Ehling et al. 2014) and carcinogenesis (Vogten et al. 2004; Dimova et al. 2014). Vascular endothelial growth factor (VEGF) receptor expression was found to be upregulated in a murine model of hepatic fibrosis (Iwakiri et al. 2014). VEGFR (VEGF receptor)-1 and VEGFR-2 neutralizing monoclonal antibodies markedly attenuated fibrosis development through suppression of neovascularization (Yoshiji et al. 2002b). Furthermore, experimental fibrosis was inhibited by the anti-angiogenic agents, angiostatin and TNP-470 (Vogten et al. 2004). Pro-angiogenic properties of Ang-II are in part facilitated by potentiating the expression of VEGF in endothelial cells (Imanishi et al. 2004).

Alpha smooth muscle actin-positive cells were significantly reduced in count by candesartan and perindopril. Ang-II activates nuclear factor kappa-B (NF-kB) pathway via AT1Rs leading to gene transcription of pro-inflammatory cytokines such as TNF- $\alpha$, IL-6, and TGF- $\beta 1$ (Wolf et al. 2002; Ozawa et al. 2007; Ruiz-Ortega et al. 2006).

The interactions of Ang-II and AT1Rs are connected to certain cardiac and renal fibro-proliferative diseases (Bascands and Schanstra 2005; Sakai et al. 2008). A normotensive mouse model of renal fibrosis found that both ramipril and candesartan postponed the onset and abolished the increase in the magnitude of proteinuria and increased survival (Gross et al. 2004).

\section{Hepatocellular carcinoma}

Hepatocellular carcinoma is the most widespread type of primary liver lesions, and it is the main consequence of cirrhosis. Numerous risk factors including hepatitis $\mathrm{C}$ virus (HCV) and hepatitis $B$ virus (HBV) infections are the main causes of high prevalence of HCC (El-Serag 2007; Nordenstedt et al. 2010; Sherman 2005; Mancuso 2017).

\section{RAS contribution to cancer development}

At a local tissue level, RAS enhances tumor growth. Immune modulatory effects (Abdel-Ghany et al. 2015), angiogenesis, mitogenesis, and ECM formation lay behind potential tumor-promoting effects of RAS (Deshayes and Nahmias 2005). Components of the RAS are frequently found overexpressed in several types of cancers such as lung, skin, cervical, pancreatic, prostate, brain, colon, and breast cancer compared to their corresponding normal tissues (Deshayes and Nahmias 2005). In particular, upregulation of the AT1R is principal. However, the expression of RAS components appears to be altered with tumor types and their grade (Louis et al. 2007).

Modulation of angiogenesis is the principal mechanism by which RAS achieves its pro-tumor effects, which is an essential step in the development of solid tumors (Saber et al. 2018c). Various pro-angiogenic mediators are activated by Ang-II including VEGF (Huang et al. 2008), angiopoietin-2 (Yasumatsu et al. 2004), basic fibroblast growth factor (b-FGF) (Wysocki et al. 2006), and platelet-derived growth factor (PDGF) (Fujita et al. 2002); these angiogenic properties are mediated by the AT1R. In addition, RAS inhibition is often accompanying a reduction in the expression of VEGF (Uemura et al. 2003; Kosaka et al. 2007; Saber et al. 2018d). In a model of ischemia-induced angiogenesis, Ang-II induces angiogenic effects in the damaged vessels by increasing expression of VEGF and upregulating endothelial NO synthase levels; these effects found to be mediated through the AT1R (Tamarat et al. 2002).

In a murine model of $\mathrm{HCC}$, angiotensin-converting enzyme inhibitors (ACEIs) have inhibited the development of HCC lesions (Yoshiji et al. 2001b). Perindopril showed a reduction in angiogenesis and tumor progression in head and neck squamous cell carcinoma (Yasumatsu et al. 2004). Also, candesartan diminished angiogenesis in different types of cancers such as the xenograft model of human prostate cancer (Kosaka et al. 2007), mouse melanoma syngeneic tumors (Egami et al. 2003), ovarian cancer cells (Suganuma et al. 2005), and murine Lewis lung cancer model (Fujita et al. 2002). In addition, captopril and irbesartan inhibited angiogenesis, carcinogenesis, and metastases in colorectal cancer liver metastases in mice (Neo et al. 2007). Therefore, RAS intensely impact the level of neovascularization.

Yoshiji et al. (2007) revealed that a dual combination of ACEI and vitamin K produced intense anti-angiogenic properties and ameliorated dysplastic nodules and effective reduction in the level of alpha fetoprotein (AFP) in cirrhotic patients; these nodules disappeared completely after 1 year of administration. Another combination of perindopril and vitamin $\mathrm{K} 2$ prevented neovascularization and the development of HCC in a report by Yoshiji et al. 
(2006). In addition, Yoshiji et al. (2002c) revealed that perindopril effectively ameliorated hepatic fibrosis and pre-neoplastic foci in two models of liver carcinogenesis. In addition, perindopril and interferon- $\beta$ at lower clinical effective doses inhibited angiogenesis and prevented tumor development that was associated with a reduction in VEGF (Noguchi et al. 2003). Furthermore, perindopril and 5-fluorouracil prevented the development of HCC by suppressing neovascularization in mice (Yanase et al. 2007).

In the clinical settings, it was reported that patients treated with sorafenib plus RAS inhibition had a better median overall survival (19.5 months) compared to those treated with either sorafenib (10.9 months) or RAS inhibition (9.7 months) alone $(p=0.043)$ (Pinter et al. 2017). Another study reported that the use of ARBs during erlotinib treatment may prolong overall survival of metastatic non-small cell lung cancer patients (Aydiner et al. 2015).

Ang-II can increase expression of ETB receptor in HSCs and induce production of ET-1 in endothelial cells (Bataller et al. 2003b; Cheng et al. 2005). ET-1 acting on ETB receptor can induce migration and proliferation of endothelial cells. Several studies proposed that ET-1 augments the pro-angiogenic effects of VEGF (Ribatti et al. 2007).

Ang-II is able to induce mitogenesis of endothelial cells, fibroblasts, and smooth muscle cells (Touyz and Schiffrin 2000) and can induce transcription of several growth-related oncogenes (Nogueira et al. 2007) and growth factors (Deshayes and Nahmias 2005) in various cells. These suggest that RAS can also affect tumor cell proliferation and survival.

Ang-II stimulates the secretion of gonocyte colonystimulating factor (GCSF), MCP-1, and MCP-2 resulting in excessive macrophage infiltration (Egami et al. 2003; Kosugi et al. 2006; Tone et al. 2007). In addition, macrophage infiltration into the tumor endorses growth and metastasis (Leek et al. 1994; van der Bij et al. 2005). Notably, M2 macrophage pathway is connected with these pro-tumor functions.

In addition, macrophage infiltration can participate in tumor metastasis at later stages when host defenses are debilitated. Regarding this situation, rapid proliferation of cancer cells enable binding of tumor cells by KCs to initiate the generation of new metastatic sites (Bayon et al. 1996). Macrophages also can secrete several cytokines facilitating tumor growth and metastases by induction of angiogenesis (Egami et al. 2003; van der Bij et al. 2005; Nishie et al. 1999).

\section{Conclusion}

A feature is now becoming clear that there is a prerequisite of using multiple drug therapy for management of liver fibrosis and HCC. This is due to the complex networks of multiple and often redundant pathways. Anti-hypertensive agents based on angiotensin II inhibition such as the ACEIs or the ARBs are of low economic cost and have already been in clinical use with their well-known safety profiles and if these drugs can inhibit the development and progression of tumors at their lowest effective clinical doses, then they may provide a useful adjunctive therapeutic strategy in the treatment of fibrosis and cancer. Therefore, angiotensin II inhibitors are promising candidates for further clinical trials in the management of liver fibrosis, cirrhosis, and HCC.

\section{Acknowledgements}

I appreciate the encouragement and support provided by staff members of Faculty of Pharmacy, Delta University for Science and Technology.

Funding

No sources of funding to be declared.

Availability of data and materials

Not applicable.

Author's contributions

SS was the only contributor in writing the manuscript. The author read and approved the final manuscript.

Ethics approval and consent to participate

Not applicable.

Consent for publication

Not applicable.

\section{Competing interests}

The author declares that he/she has no competing interests.

\section{Publisher's Note}

Springer Nature remains neutral with regard to jurisdictional claims in published maps and institutional affiliations.

Received: 9 August 2018 Accepted: 22 October 2018

Published online: 03 November 2018

\section{References}

Abdel-Ghany R, Rabia I, El-Ahwany E, Saber S, Gamal R, Nagy F et al (2015) Blockade of PGE2, PGD2 receptors confers protection against Prepatent schistosomiasis Mansoni in mice. J Egypt Soc Parasitol 45(3):511-520

Ahmadian E, Pennefather PS, Eftekhari A, Heidari R, Eghbal MA (2016) Role of renin-angiotensin system in liver diseases: an outline on the potential therapeutic points of intervention. Expert review of gastroenterology \& hepatology 10(11):1279-1288

Arpino V, Brock M, Gill SE (2015) The role of TIMPs in regulation of extracellular matrix proteolysis. Matrix Biol 44:247-254

Arthur MJ (2000) Fibrogenesis II. Metalloproteinases and their inhibitors in liver fibrosis. Am J Physiol Gastrointest Liver Physiol 279(2):G245-G249

Aydiner A, Ciftci R, Sen F (2015) Renin-angiotensin system blockers may prolong survival of metastatic non-small cell lung cancer patients receiving erlotinib. Medicine 94(22):e887

Baiocchini A, Montaldo C, Conigliaro A, Grimaldi A, Correani V, Mura F et al (2016) Extracellular matrix molecular remodeling in human liver fibrosis evolution. PLoS One 11(3):e0151736

Bascands JL, Schanstra JP (2005) Obstructive nephropathy: insights from genetically engineered animals. Kidney Int 68(3):925-937

Bataller R, Brenner DA (2005) Liver fibrosis. J Clin Invest 115(2):209-218

Bataller R, Gabele E, Schoonhoven R, Morris T, Lehnert M, Yang L et al (2003a) Prolonged infusion of angiotensin II into normal rats induces stellate cell 
activation and proinflammatory events in liver. Am J Physiol Gastrointest Liver Physiol 285(3):G642-G651

Bataller R, Sancho-Bru P, Gines P, Lora JM, Al-Garawi A, Sole M et al (2003b) Activated human hepatic stellate cells express the reninangiotensin system and synthesize angiotensin II. Gastroenterology 125(1):117-125

Bayon LG, Izquierdo MA, Sirovich I, van Rooijen N, Beelen RH, Meijer S (1996) Role of Kupffer cells in arresting circulating tumor cells and controlling metastatic growth in the liver. Hepatology 23(5):1224-1231

Beljaars L, Meijer DK, Poelstra K (2002) Targeting hepatic stellate cells for cellspecific treatment of liver fibrosis. Frontiers in bioscience : a journal and virtual library. 7:e214-e222

Caley MP, Martins VL, O'Toole EA (2015) Metalloproteinases and wound healing. Advances in wound care 4(4):225-234

Cheng ZJ, Vapaatalo H, Mervaala E (2005) Angiotensin II and vascular inflammation. Medical science monitor : international medical journal of experimental and clinical research 11(6):RA194-RA205

Cho JJ, Hocher B, Herbst H, Jia JD, Ruehl M, Hahn EG et al (2000) An oral endothelin-a receptor antagonist blocks collagen synthesis and deposition in advanced rat liver fibrosis. Gastroenterology 118(6):1169-1178

Correia-Costa L, Morato M, Sousa T, Cosme D, Guimarães JT, Guerra A et al (2016) Urinary fibrogenic cytokines ET-1 and TGF- $\beta 1$ are associated with urinary angiotensinogen levels in obese children. Pediatr Nephrol 31(3):455-464

Deshayes F, Nahmias C (2005) Angiotensin receptors: a new role in cancer? Trends Endocrinol Metab 16(7):293-299

de Oliveira da Silva B, Ramos LF, Moraes KC (2017) Molecular interplays in hepatic stellate cells: apoptosis, senescence, and phenotype reversion as cellular connections that modulate liver fibrosis. Cell Biol Int 41(9): 946-59.

Dimova I, Popivanov G, Djonov V (2014) Angiogenesis in cancer-general pathways and their therapeutic implications. Jbuon 19(1):15-21

Egami K, Murohara T, Shimada T, Sasaki K, Shintani S, Sugaya T et al (2003) Role of host angiotensin II type 1 receptor in tumor angiogenesis and growth. J Clin Invest 112(1):67-75

Ehling J, Bartneck M, Wei X, Gremse F, Fech V, Möckel D et al (2014) CCL2dependent infiltrating macrophages promote angiogenesis in progressive liver fibrosis. Gut 63(12):1960-1971

El-Serag HB (2007) Epidemiology of hepatocellular carcinoma in USA. Hepatology research : the official journal of the Japan Society of Hepatology 37(Suppl 2): S88-S94

Fujita M, Hayashi I, Yamashina S, Itoman M, Majima M (2002) Blockade of angiotensin AT1a receptor signaling reduces tumor growth, angiogenesis, and metastasis. Biochem Biophys Res Commun 294(2):441-447

Gabele E, Brenner DA, Rippe RA (2003) Liver fibrosis: signals leading to the amplification of the fibrogenic hepatic stellate cell. Frontiers in bioscience : a journal and virtual library 8:d69-d77

Gressner AM, Weiskirchen R, Breitkopf K, Dooley S (2002) Roles of TGF-beta in hepatic fibrosis. Frontiers in bioscience : a journal and virtual library. 7:d793-d807

Gross O, Schulze-Lohoff E, Koepke ML, Beirowski B, Addicks K, Bloch W et al (2004) Antifibrotic, nephroprotective potential of ACE inhibitor vs AT1 antagonist in a murine model of renal fibrosis. Nephrology, dialysis, transplantation : official publication of the European Dialysis and Transplant Association - European Renal Association. 19(7):1716-1723

Han J, Zou C, Mei L, Zhang Y, Qian Y, You S et al (2017) MD2 mediates angiotensin II-induced cardiac inflammation and remodeling via directly binding to Ang II and activating TLR4/NF-KB signaling pathway. Basic Res Cardiol 112(1):9

Hayes CN, Chayama K (2016) MicroRNAs as biomarkers for liver disease and hepatocellular carcinoma. Int J Mol Sci 17(3):280

Huang H, Zhou J, Cui Z, Wang B, Hu Y (2015) Angiotensin II type 1 receptorassociated protein plays a role in regulating the local renin-angiotensin system in HSC-T6 cells. Mol Med Rep 12(3):3763-3768

Huang W, Wu YL, Zhong J, Jiang FX, Tian XL, Yu LF (2008) Angiotensin II type 1 receptor antagonist suppress angiogenesis and growth of gastric cancer xenografts. Dig Dis Sci 53(5):1206-1210

Huskic J, Kulenovic H, Kardum D, Babic N, Knezevic Z (1999) Serum angiotensin converting enzyme in patients with primary liver carcinoma. Med Arh 53(2):61-63

Hyun J, Wang S, Kim J, Rao KM, Park SY, Chung I et al (2016) MicroRNA-378 limits activation of hepatic stellate cells and liver fibrosis by suppressing Gli3 expression. Nat Commun 7:10993
Imanishi T, Hano T, Nishio I (2004) Angiotensin II potentiates vascular endothelial growth factor-induced proliferation and network formation of endothelial progenitor cells. Hypertens Res 27(2):101-108

Iredale JP (1997) Tissue inhibitors of metalloproteinases in liver fibrosis. Int J Biochem Cell Biol 29(1):43-54

Iredale JP, Benyon RC, Pickering J, McCullen M, Northrop M, Pawley S et al (1998) Mechanisms of spontaneous resolution of rat liver fibrosis. Hepatic stellate cell apoptosis and reduced hepatic expression of metalloproteinase inhibitors. J Clin Invest 102(3):538-549

Iwakiri Y (2015) Nitric oxide in liver fibrosis: the role of inducible nitric oxide synthase. Clinical and molecular hepatology 21(4):319

Iwakiri Y, Shah V, Rockey DC (2014) Vascular pathobiology in chronic liver disease and cirrhosis-current status and future directions. J Hepatol 61(4):912-924

Jonsson JR, Clouston AD, Ando Y, Kelemen LI, Horn MJ, Adamson MD et al (2001) Angiotensin-converting enzyme inhibition attenuates the progression of rat hepatic fibrosis. Gastroenterology 121(1):148-155

Karsan HA, Rojter SE, Saab S (2004) Primary prevention of cirrhosis. Public health strategies that can make a difference Postgrad Med 115(1):25-30

Kaviratne M, Hesse M, Leusink M, Cheever AW, Davies SJ, McKerrow JH et al (2004) IL-13 activates a mechanism of tissue fibrosis that is completely TGFbeta independent. J Immunol 173(6):4020-4029

Kosaka T, Miyajima A, Takayama E, Kikuchi E, Nakashima J, Ohigashi T et al (2007) Angiotensin II type 1 receptor antagonist as an angiogenic inhibitor in prostate cancer. Prostate 67(1):41-49

Kosugi M, Miyajima A, Kikuchi E, Horiguchi Y, Murai M (2006) Angiotensin II type 1 receptor antagonist candesartan as an angiogenic inhibitor in a xenograft model of bladder cancer. Clin Cancer Res 12(9):2888-2893

Lan T, Kisseleva T, Brenner DA (2015) Deficiency of NOX1 or NOX4 prevents liver inflammation and fibrosis in mice through inhibition of hepatic stellate cell activation. PLoS One 10(7):e0129743

Leek RD, Harris AL, Lewis CE (1994) Cytokine networks in solid human tumors: regulation of angiogenesis. J Leukoc Biol 56(4):423-435

Leung PS, Suen PM, Ip SP, Yip CK, Chen G, Lai PB (2003) Expression and localization of AT1 receptors in hepatic Kupffer cells: its potential role in regulating a fibrogenic response. Regul Pept 116(1-3):61-69

Lindquist JN, Marzluff WF, Stefanovic B (2000) Fibrogenesis. III. Posttranscriptional regulation of type I collagen. Am J Physiol Gastrointest Liver Physiol 279(3):G471-G476

Liu BC, Xia HL, Wu JN, Zhang XL, Liu DG, Gong YX (2007) Influence of irbesartan on expression of ILK and its relationship with epithelial-mesenchymal transition in mice with unilateral ureteral obstruction. Acta Pharmacol Sin 28(11):1810-1818

Louis SN, Wang L, Chow L, Rezmann LA, Imamura K, MacGregor DP et al (2007) Appearance of angiotensin II expression in non-basal epithelial cells is an early feature of malignant change in human prostate. Cancer Detect Prev 31(5):391-395

Maher JJ (2001) Interactions between hepatic stellate cells and the immune system. Semin Liver Dis 21(3):417-426

Mancuso A (2017) Regorafenib for hepatocellular carcinoma progressing on sorafenib: just another starting point. AME Medical Journal 2(31):1-3

Marra F (1999) Hepatic stellate cells and the regulation of liver inflammation. J Hepatol 31(6):1120-1130

Marra F (2002) Chemokines in liver inflammation and fibrosis. Frontiers in bioscience : a journal and virtual library. 7:d1899-d1914

Meng G, Zhu J, Xiao Y, Huang Z, Zhang Y, Tang X, et al (2015) Hydrogen sulfide donor GYY4137 protects against myocardial fibrosis. Oxidative Med Cell Longev 1:14

Milani S, Herbst H, Schuppan D, Kim KY, Riecken EO, Stein H (1990) Procollagen expression by nonparenchymal rat liver cells in experimental biliary fibrosis. Gastroenterology 98(1):175-184

Neo JH, Malcontenti-Wilson C, Muralidharan V, Christophi C (2007) Effect of ACE inhibitors and angiotensin $\|$ receptor antagonists in a mouse model of colorectal cancer liver metastases. J Gastroenterol Hepatol 22(4):577-584

Nguyen L, Ager El, Neo J, Christophi C (2016) Regulation of colorectal cancer cell epithelial to mesenchymal transition by the renin angiotensin system. J Gastroenterol Hepatol 31(10):1773-1782

Nishie A, Ono M, Shono T, Fukushi J, Otsubo M, Onoue H et al (1999) Macrophage infiltration and heme oxygenase-1 expression correlate with angiogenesis in human gliomas. Clin Cancer Res 5(5):1107-1113 
Noguchi R, Kaji K, Namisaki T, Moriya K, Kitade M, Takeda K et al (2017) Serum angiotensin-converting enzyme level for evaluating significant fibrosis in chronic hepatitis B. World J Gastroenterol 23(36):6705

Noguchi R, Yoshiji H, Kuriyama S, Yoshii J, Ikenaka Y, Yanase K et al (2003) Combination of interferon-beta and the angiotensin-converting enzyme inhibitor, perindopril, attenuates murine hepatocellular carcinoma development and angiogenesis. Clinical cancer research : an official journal of the American Association for Cancer Research 9(16 Pt 1):6038-6045

Nogueira EF, Vargas CA, Otis M, Gallo-Payet N, Bollag WB, Rainey WE (2007) Angiotensin-II acute regulation of rapid response genes in human, bovine, and rat adrenocortical cells. J Mol Endocrinol 39(6):365-374

Nordenstedt H, White DL, El-Serag HB (2010) The changing pattern of epidemiology in hepatocellular carcinoma. Dig Liver Dis 42(Suppl 3): S206-S214

Oben JA, Diehl AM (2004) Sympathetic nervous system regulation of liver repair. Anat Rec A Discov Mol Cell Evol Biol 280(1):874-883

Ozawa Y, Kobori H, Suzaki Y, Navar LG (2007) Sustained renal interstitial macrophage infiltration following chronic angiotensin II infusions. American journal of physiology Renal physiology 292(1):F330-F339

Paizis G, Cooper ME, Schembri JM, Tikellis C, Burrell LM, Angus PW (2002) Upregulation of components of the renin-angiotensin system in the bile ductligated rat liver. Gastroenterology 123(5):1667-1676

Parsons CJ, Takashima M, Rippe RA (2007) Molecular mechanisms of hepatic fibrogenesis. J Gastroenterol Hepatol 22:S79-S84.

Pinter M, Weinmann A, Wörns M-A, Hucke F, Bota S, Marquardt JU et al (2017) Use of inhibitors of the renin-angiotensin system is associated with longer survival in patients with hepatocellular carcinoma. United European Gastroenterol J 5(7):987-996

Poynard T, Lebray P, Ingiliz P, Varaut A, Varsat B, Ngo Y et al (2010) Prevalence of liver fibrosis and risk factors in a general population using non-invasive biomarkers (FibroTest). BMC Gastroenterol 10(1):40

Ribatti D, Conconi MT, Nussdorfer GG (2007) Nonclassic endogenous novel [corrected] regulators of angiogenesis. Pharmacol Rev 59(2):185-205

Riether C, Schürch C, Ochsenbein A (2015) Regulation of hematopoietic and leukemic stem cells by the immune system. Cell Death \& Differentiation 22(2):187-198

Rippe RA, Brenner DA (2004) From quiescence to activation: gene regulation in hepatic stellate cells. Gastroenterology 127(4):1260-1262

Ruiz-Ortega M, Ruperez M, Esteban V, Rodriguez-Vita J, Sanchez-Lopez E, Carvajal $G$ et al (2006) Angiotensin II: a key factor in the inflammatory and fibrotic response in kidney diseases. Nephrology, dialysis, transplantation : official publication of the European Dialysis and Transplant Association - European Renal Association 21(1):16-20

Saber S, Goda R, El-Tanbouly GS, Ezzat D (2018a) Lisinopril inhibits nuclear transcription factor kappa $B$ and augments sensitivity to silymarin in experimental liver fibrosis. Int Immunopharmacol 64:340-349

Saber S, Mahmoud A, Helal N, El-Ahwany E, Abdelghany R (2018c) Liver protective effects of renin-angiotensin system inhibition have no survival benefits in hepatocellular carcinoma induced by repetitive Administration of Diethylnitrosamine in mice. Open Access Macedonian Journal of Medical Sciences 6(6):955-1179

Saber S, Mahmoud AA, Helal NS, El-Ahwany E, Abdelghany RH (2017) Losartan, an angiotensin-II type 1 receptor blocker, attenuates CCl4-induced liver fibrosis with a positive impact on survival in mice. World J Pharm Pharm Sci 5(12):121-126

Saber S, Mahmoud AAA, Goda R, Helal NS, El-ahwany E, Abdelghany RH (2018d) Perindopril, fosinopril and losartan inhibited the progression of diethylnitrosamine-induced hepatocellular carcinoma in mice via the inactivation of nuclear transcription factor kappa-B. Toxicol Lett 295:32-40

Saber S, Mahmoud AAA, Helal NS, El-Ahwany E, Abdelghany RH (2018b) Reninangiotensin system inhibition ameliorates CCl4-induced liver fibrosis in mice through the inactivation of nuclear transcription factor kappa B. Can J Physiol Pharmacol 96(6):569-576

Sakai N, Wada T, Matsushima K, Bucala R, Iwai M, Horiuchi M et al (2008) The renin-angiotensin system contributes to renal fibrosis through regulation of fibrocytes. J Hypertens 26(4):780-790

Sayyed HG, Osama A, Idriss NK, Sabry D, Abdelrhim AS, Bakry R (2016) Comparison of the therapeutic effectiveness of human CD34+ and rat bone marrow mesenchymal stem cells on improvement of experimental liver fibrosis in Wistar rats. International journal of physiology, pathophysiology and pharmacology 8(3):128
Schon H-T, Bartneck M, Borkham-Kamphorst E, Nattermann J, Lammers T, Tacke F, et al (2016) Pharmacological intervention in hepatic stellate cell activation and hepatic fibrosis. Front Pharmacol 7:33

Schuppan D, Afdhal NH (2008) Liver cirrhosis. Lancet 371(9615):838-851

Schwabe RF, Bataller R, Brenner DA (2003) Human hepatic stellate cells express CCR5 and RANTES to induce proliferation and migration. Am J Physiol Gastrointest Liver Physiol 285(5):G949-G958

Shek FW, Benyon RC (2004) How can transforming growth factor beta be targeted usefully to combat liver fibrosis? Eur J Gastroenterol Hepatol 16(2): 123-126

Sherman M (2005) Hepatocellular carcinoma: epidemiology, risk factors, and screening. Semin Liver Dis 25(2):143-154

Sudo K, Yamada Y, Moriwaki H, Saito K, Seishima M (2005) Lack of tumor necrosis factor receptor type 1 inhibits liver fibrosis induced by carbon tetrachloride in mice. Cytokine 29(5):236-244

Suganuma T, Ino K, Shibata K, Kajiyama H, Nagasaka T, Mizutani S et al (2005) Functional expression of the angiotensin II type 1 receptor in human ovarian carcinoma cells and its blockade therapy resulting in suppression of tumor invasion, angiogenesis, and peritoneal dissemination. Clin Cancer Res 11(7): 2686-2694

Sui X, Wei H, Wang D (2015) Novel mechanism of cardiac protection by valsartan: synergetic roles of TGF- $\beta 1$ and HIF-1a in Ang II-mediated fibrosis after myocardial infarction. J Cell Mol Med 19(8):1773-1782

Tamarat R, Silvestre JS, Kubis N, Benessiano J, Duriez M, deGasparo M et al (2002) Endothelial nitric oxide synthase lies downstream from angiotensin Iinduced angiogenesis in ischemic hindlimb. Hypertension 39(3):830-835

Tone A, Shikata K, Ogawa D, Sasaki S, Nagase R, Sasaki M et al (2007) Changes of gene expression profiles in macrophages stimulated by angiotensin $\|--$ angiotensin II induces MCP-2 through AT1-receptor. Journal of the reninangiotensin-aldosterone system : JRAAS 8(1):45-50

Touyz RM, Schiffrin EL (2000) Signal transduction mechanisms mediating the physiological and pathophysiological actions of angiotensin II in vascular smooth muscle cells. Pharmacol Rev 52(4):639-672

Uemura $\mathrm{H}$, Ishiguro $\mathrm{H}$, Nakaigawa N, Nagashima $Y$, Miyoshi $Y$, Fujinami $\mathrm{K}$ et al (2003) Angiotensin II receptor blocker shows antiproliferative activity in prostate cancer cells: a possibility of tyrosine kinase inhibitor of growth factor. Mol Cancer Ther 2(11):1139-1147

van der Bij GJ, Oosterling SJ, Meijer S, Beelen RH, van Egmond M (2005) Therapeutic potential of Kupffer cells in prevention of liver metastases outgrowth. Immunobiology 210(2-4):259-265

Vinas O, Bataller R, Sancho-Bru P, Gines P, Berenguer C, Enrich C et al (2003) Human hepatic stellate cells show features of antigen-presenting cells and stimulate lymphocyte proliferation. Hepatology 38(4):919-929

Vogten JM, Drixler TA, te Velde EA, Schipper ME, van Vroonhoven TJ, Voest EE et al (2004) Angiostatin inhibits experimental liver fibrosis in mice. Int J Color Dis 19(4):387-394

Wang P, Koyama Y, Liu X, Xu J, Ma H-Y, Liang S, et al (2016) Promising therapy candidates for liver fibrosis. Front Physiol 7:47

Wolf G, Wenzel U, Burns KD, Harris RC, Stahl RA, Thaiss F (2002) Angiotensin II activates nuclear transcription factor-kappaB through AT1 and AT2 receptors. Kidney Int 61(6):1986-1995

Wysocki PJ, Kwiatkowska EP, Kazimierczak U, Suchorska W, Kowalczyk DW, Mackiewicz A (2006) Captopril, an angiotensin-converting enzyme inhibitor, promotes growth of immunogenic tumors in mice. Clin Cancer Res 12(13): 4095-4102

Xu F, Liu C, Zhou D, Zhang L (2016) TGF- $\beta / S M A D$ pathway and its regulation in hepatic fibrosis. Journal of Histochemistry \& Cytochemistry 64(3):157-167

Yanase K, Yoshiji H, Ikenaka Y, Noguchi R, Kitade M, Kaji K et al (2007) Synergistic inhibition of hepatocellular carcinoma growth and hepatocarcinogenesis by combination of 5-fluorouracil and angiotensin-converting enzyme inhibitor via anti-angiogenic activities. Oncol Rep 17(2):441-446

Yao HW, Li J, Chen JQ, Xu SY (2004a) Inhibitory effect of leflunomide on hepatic fibrosis induced by CCl4 in rats. Acta Pharmacol Sin 25(7):915-920

Yao HW, Xie QM, Chen JQ, Deng YM, Tang HF (2004b) TGF-beta1 induces alveolar epithelial to mesenchymal transition in vitro. Life Sci 76(1):29-37

Yasumatsu R, Nakashima T, Masuda M, Ito A, Kuratomi Y, Nakagawa T et al (2004) Effects of the angiotensin-I converting enzyme inhibitor perindopril on tumor growth and angiogenesis in head and neck squamous cell carcinoma cells. J Cancer Res Clin Oncol 130(10):567-573

Yoshiji H, Kuriyama S, Fukui H (2002a) Angiotensin-l-converting enzyme inhibitors may be an alternative anti-angiogenic strategy in the treatment of liver 
fibrosis and hepatocellular carcinoma. Possible role of vascular endothelial growth factor. Tumour Biol 23(6):348-356

Yoshiji H, Kuriyama S, Fukui H (2002b) Perindopril: possible use in cancer therapy. Anti-Cancer Drugs 13(3):221-228

Yoshiji H, Kuriyama S, Kawata M, Yoshii J, Ikenaka Y, Noguchi R et al (2001 b) The angiotensin-l-converting enzyme inhibitor perindopril suppresses tumor growth and angiogenesis: possible role of the vascular endothelial growth factor. Clin Cancer Res 7(4):1073-1078

Yoshiji H, Kuriyama S, Miyamoto Y, Thorgeirsson UP, Gomez DE, Kawata M et al (2000) Tissue inhibitor of metalloproteinases-1 promotes liver fibrosis development in a transgenic mouse model. Hepatology 32(6):1248-1254

Yoshiji H, Kuriyama S, Noguchi R, Yoshii J, Ikenaka Y, Yanase K et al (2005) Combination of interferon-beta and angiotensin-converting enzyme inhibitor, perindopril, attenuates the murine liver fibrosis development. Liver Int 25(1):153-161

Yoshiji H, Kuriyama S, Noguchi R, Yoshii J, Ikenaka Y, Yanase K et al (2006) Amelioration of carcinogenesis and tumor growth in the rat liver by combination of vitamin $\mathrm{K} 2$ and angiotensin-converting enzyme inhibitor via anti-angiogenic activities. Oncol Rep 15(1):155-159

Yoshiji H, Kuriyama S, Yoshii J, Ikenaka Y, Noguchi R, Nakatani T et al (2001a) Angiotensin-ll type 1 receptor interaction is a major regulator for liver fibrosis development in rats. Hepatology 34(4 Pt 1):745-750

Yoshiji H, Kuriyama S, Yoshii J, Ikenaka Y, Noguchi R, Yanase K et al (2003) Angiotensin-II induces the tissue inhibitor of metalloproteinases-1 through the protein kinase-C signaling pathway in rat liver fibrosis development. Hepatology research : the official journal of the Japan Society of Hepatology. 27(1):51-56

Yoshiji H, Noguchi R, Yamazaki M, Ikenaka Y, Sawai M, Ishikawa M et al (2007) Combined treatment of vitamin $\mathrm{K} 2$ and angiotensin-converting enzyme inhibitor ameliorates hepatic dysplastic nodule in a patient with liver cirrhosis. World J Gastroenterol 13(23):3259-3261

Yoshiji H, Yoshii J, Ikenaka Y, Noguchi R, Tsujinoue H, Nakatani T et al (2002c) Inhibition of renin-angiotensin system attenuates liver enzyme-altered preneoplastic lesions and fibrosis development in rats. J Hepatol 37(1):22-30

\section{Submit your manuscript to a SpringerOpen ${ }^{\circ}$ journal and benefit from:}

- Convenient online submission

- Rigorous peer review

- Open access: articles freely available online

High visibility within the field

- Retaining the copyright to your article

Submit your next manuscript at $\boldsymbol{\nabla}$ springeropen.com 